\title{
Species-specific effects of herbivorous fishes on the establishment of the macroalga Lobophora on coral reefs
}

\author{
Laura D. Puk ${ }^{1,2, *}$, Nicole Cernohorsky ${ }^{3}$, Alyssa Marshell ${ }^{4}$, John Dwyer ${ }^{1}$, \\ Kennedy Wolfe ${ }^{1,2}$, Peter J. Mumby ${ }^{1,2,5}$ \\ ${ }^{1}$ School of Biological Sciences, University of Queensland, St Lucia, QLD 4072, Australia \\ ${ }^{2}$ ARC Center of Excellence for Coral Reef Studies, James Cook University, Townsville 4811, QLD, Australia \\ ${ }^{3}$ Department of Botany and Zoology, Faculty of Science, Masaryk University, 61137 Brno, Czech Republic \\ ${ }^{4}$ Department of Marine Science and Fisheries, Sultan Qaboos University, 123 Muscat, Oman \\ ${ }^{5}$ Palau International Coral Reef Center, PO Box 7096, Koror 96940, Republic of Palau
}

\begin{abstract}
Herbivory is a key ecosystem function that influences ecosystem trajectories. However, interactions between plants and herbivores are species-specific and change throughout the plants' lifetime. On coral reefs, herbivorous fishes reduce competition between corals and macroalgae through their grazing activity, thereby regulating the ecosystem state. Grazing vulnerability of marine algae generally decreases with increasing algal size. Therefore, the removal of newly settled recruits by herbivorous fish is likely important in preventing macroalgal blooms and reducing competition with corals. We studied the grazing susceptibility of recruits of the brown macroalga Lobophora to multiple fish species through a combination of feeding observations and manipulative in situ and ex situ experiments. Further, we recorded short-term Lobophora growth patterns and adult survival over $9 \mathrm{wk}$. Lobophora recruits were more susceptible to herbivory than adults, likely owing to their smaller size. However, recruit mortality was driven by only 3 of the studied species: Acanthurus nigrofuscus, Scarus niger and Chlorurus spilurus, whereas other common herbivores did not remove any Lobophora recruits. Our data also suggest variable growth and recruitment among months. These findings point to a possible increase in grazing resistance with age for Lobophora. As such, a decrease in grazing pressure by key fish species controlling Lobophora recruits could permit Lobophora to establish more grazingtolerant adult populations.
\end{abstract}

${ }^{*}$ Corresponding author: 1.puk@uqconnect.edu.au

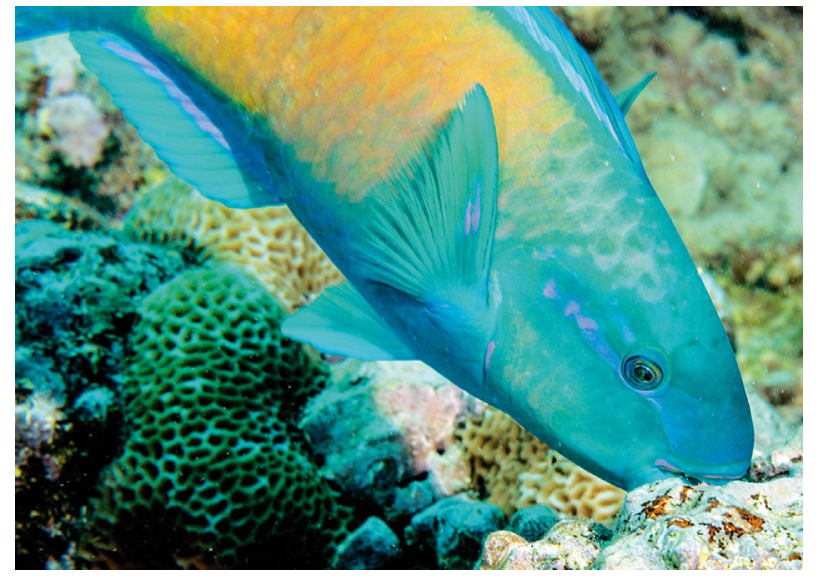

The parrotfish Chlorurus spilurus feeding on coral reef substrate covered with turf and macroalgae.

Photo: Peter J. Mumby

KEY WORDS: Ontogeny $\cdot$ Algae $\cdot$ Herbivory $\cdot$ Phase shift $\cdot$ Seaweed $\cdot$ Diversity $\cdot$ Propagule

\section{INTRODUCTION}

Herbivory can exert strong impacts on plant community structure, but the effect varies depending on the plant and herbivore species involved (Gruner et al. 2008, Barton \& Koricheva 2010). Plants regulate their grazing susceptibility through a variety of defence mechanisms, such as physical defences, for

(C) The authors 2020. Open Access under Creative Commons by Attribution Licence. Use, distribution and reproduction are unrestricted. Authors and original publication must be credited. 
example through the development of tough leaves (Gilbert 1971, Kearsley \& Whitham 1989, Loney et al. 2006), or chemical defences such as secondary metabolites that deter herbivores (Feeny 1970, Whittaker \& Feeny 1971, McConnell et al. 1982). Grazing susceptibility can change throughout ontogeny (e.g. Cipollini \& Redman 1999, Fritz et al. 2001, Goodger et al. 2006), often decreasing with age, as predicted by the 'growth-differentiation balance' (Herms \& Mattson 1992). In contrast, the 'plant-age hypothesis' predicts higher levels of defence in the most vulnerable stages, such as juvenile plants (Bryant et al. 1992, sensu Spiegel \& Price 1996). Numerous studies have provided supporting evidence for both hypotheses (e.g. Lubchenco 1983, Cipollini \& Redman 1999, Fritz et al. 2001, Goodger et al. 2006), but a meta-analysis of these patterns found little support for decreasing defences in plants as they mature (Barton \& Koricheva 2010). Instead, increased consumption of older plants was driven by herbivore species-specific preferences without an associated decrease in plant defences (Barton \& Koricheva 2010), highlighting the fact that ontogenetic changes in grazing susceptibility of plants depend on the herbivore species involved.

In tropical marine systems, herbivory is intense and herbivorous fishes play an important role in regulating algae (Carpenter 1986, Polunin \& Klumpp 1992). On coral reefs, macroalgae often compete with reefbuilding corals for space, a major limiting resource (Connell et al. 1997, Miller et al. 1999). Reefs dominated by corals provide habitat to numerous species and deliver ecosystem services to millions of people living close to tropical coastlines (Moberg \& Folke 1999). However, increasing anthropogenic impacts have shifted the balance in favour of algae, which has caused an increase in macroalgae on many of the world's reefs (Hughes 1994, McClanahan \& Muthiga 1998). While macroalgae can have a variety of negative influences on corals (e.g. Jompa \& McCook 2002a,b, Nyström et al. 2008, Rasher \& Hay 2010), upright macroalgae can also provide habitat to fish, especially juveniles (Dahlgren \& Eggleston 2000, Evans et al. 2014). It is therefore important to understand the role herbivorous coral reef fishes play in preventing macroalgal proliferation. While some notionally herbivorous fishes acquire their nutrition from other organisms, here, we will refer to 'herbivores' from an ecological perspective, i.e. if they cause biologically mediated disturbance to algae (sensu Steneck et al. 2017).

The removal and digestion of adult brown macroalgae, a common macroalgal group involved in phase shifts on coral reefs (e.g. Bellwood et al. 2006, Ledlie et al. 2007, Roff et al. 2015), is difficult and therefore confined to specialised herbivorous fish species ('browsers'; Green \& Bellwood 2009). Brown macroalgae store their energy in mannitol and laminarin, polysaccharides that are difficult to digest by vertebrates (Saunders \& Wiggins 1981, Painter 1983). There is no evidence of fish being able to produce proteins that would enable them to break down these macroalgal polysaccharides (Clements \& Choat 1997). In order to derive nutrition from brown macroalgae, common 'browsing' fish species, such as unicornfishes (nasids) and rudderfishes (kyphosids; Puk et al. 2016), have a hindgut caecum which harbours microorganisms (Horn 1989, Seeto et al. 1996). These microorganisms are capable of fermenting mannitol and laminarin and convert them into short-chained fatty acids (SCFAs), which are digestible by fish (Clements et al. 1994, Seeto et al. 1996). However, herbivores first need to deal with the physical removal of macroalgae. Several algal species are readily removed (Mantyka \& Bellwood 2007, Fox \& Bellwood 2008), while others may present a more challenging resource because of their calcified or encrusting morphology (Paul \& Hay 1986, Coen \& Tanner 1989). Some fish species, such as parrotfishes, are better equipped than others to remove tough or encrusting algae because of their strong jaws and scraping or excavating feeding habit, which allows them to remove parts of the reef substrate, including the endolithic organisms growing within it (Bellwood \& Choat 1990). Many brown macroalgae also have high levels of polyphenolics, which can hinder the herbivores' protein assimilation by forming hydrogen bonds (Stern et al. 1996). Still, some fish species, such as parrotfishes, may be unaffected by these polyphenolics because they have a basic gut environment that inhibits hydrogen bonding (Horn 1989, Appel 1993). However, parrotfishes have been identified as microphages, which target microorganisms, including cyanobacteria (Clements et al. 2017). Therefore, while parrotfishes may incidentally remove macroalgae when foraging for epiphytic microorganisms, they are not expected to target macroalgae (although the genus Sparisoma in the Atlantic is an exception; Targett et al. 1995). Other groups, such as nasids and kyphosids, which can acquire nutrition from macroalgae with the help of microorganisms (Horn 1989), will target macroalgae as their main source of nutrition but may be restricted in their ability to remove encrusting species.

It is commonly assumed that a large number of grazing fishes which target smaller turf algae incidentally ingest macroalgal recruits while foraging 
(Green \& Bellwood 2009). While macroalgal recruits are readily removed in situ (Diaz-Pulido \& McCook 2003), limited empirical evidence identifies the fish species involved in this removal. Recruits of the brown macroalga Sargassum sp. were consumed by all roving herbivorous species tested (Marshell 2014), indicating that some macroalgal species are readily consumed by most herbivorous fishes on coral reefs. However, other macroalgae may differ in their defences against herbivorous fishes.

A common macroalga that has multiple detrimental effects on corals is the genus Lobophora (e.g. Jompa \& McCook 2002a,b, Nyström et al. 2008, Rasher \& Hay 2010). Lobophora impacts multiple life history stages of corals because it decreases coral fecundity (Foster et al. 2008), inhibits coral larval settlement (Kuffner et al. 2006, Evensen et al. 2019) and growth (Box \& Mumby 2007), and can even overgrow some live corals (Ferrari et al. 2012, Vieira et al. 2015). Lobophora is a brown alga with an encrusting to foliose morphology (Vieira et al. 2014). The alga has reproductive thalli year-round (de Ruyter van Steveninck \& Breeman 1987a) and is believed to reproduce monthly (C. Vieira pers. comm.), but its dispersal range is limited (de Ruyter van Steveninck \& Breeman 1987b). Turnover rates of individual Lobophora thalli are high, with blades exhibiting half-lives of 15 to $39 \mathrm{~d}$ (de Ruyter van Steveninck \& Breeman 1987b). In contrast to upright macroalgae (Dahlgren \& Eggleston 2000, Evans et al. 2014), its encrusting growth form likely provides little refuge to larger species such as fish.

Reports of effective herbivory on the alga vary (e.g. Hay 1981, de Ruyter van Steveninck \& Breeman 1987b, Jompa \& McCook 2002a), possibly driven by different morphologies (Coen \& Tanner 1989), chemical defences (Paul \& Hay 1986, Arnold et al. 1995), induced defences (Weidner et al. 2004) and a large cryptic diversity (Sun et al. 2012, Vieira et al. 2014) where different species, albeit morphologically similar, may vary in their susceptibility to herbivores. However, a recent study demonstrated a limited role of chemistry and morphology on grazing susceptibility of Lobophora (Vieira et al. 2019). Herbivorous fishes and sea urchins are known to graze on Lobophora (Vieira et al. 2019), with Diadema sea urchins shown to have a considerable influence on Lobophora cover (de Ruyter van Steveninck \& Breeman 1987 a, Hernández et al. 2008). Like many other macroalgae, Lobophora may exhibit a strong ontogenetic shift in its susceptibility to grazing, as recruits were removed readily, whereas adult algal control was limited (Diaz-Pulido \& McCook 2003).
However, which herbivores are able to remove Lobophora recruits is unknown.

Here, we examined the role of several common fish 'herbivores' in the control of the common brown macroalgal genus Lobophora. We used a series of field and tank experiments to examine whether Lobophora is primarily controlled at its recruit or adult stage and identified the fish species able to remove Lobophora recruits, which may inform efforts to protect key species that help prevent algal blooms.

\section{MATERIALS AND METHODS}

\subsection{Study site}

The field experiments were conducted on Lighthouse Reef in the Pacific island nation of Palau $\left(07^{\circ}\right.$ $16^{\prime} 27.9^{\prime \prime} \mathrm{N}, 134^{\circ} 27^{\prime} 31.0^{\prime \prime}$ E). Lighthouse Reef lies on the eastern coast of Palau and experiences medium wave exposure. This reef used to have high coral cover $(77 \%)$ until typhoon Bopha destroyed nearly all corals in December 2012 (Roff et al. 2015). Consequently, the reef experienced a bloom of the red alga Liagora sp., which disappeared 6 mo later (Roff et al. 2015) but left in its wake a Lobophora sp. bloom which reached a maximum cover of $40 \%$ and persisted for over $2 \mathrm{yr}$ (Bozec et al. 2019). Most of the Lobophora specimens at the study site were dark brown in colour and had an encrusting to decumbent morphology.

\subsection{Experimental design}

\subsubsection{Adult Lobophora dynamics and impact of fish herbivory}

Three sites, $>100 \mathrm{~m}$ apart, were chosen on Lighthouse Reef (Site 1: $07^{\circ} 16^{\prime} 30.3^{\prime \prime} \mathrm{N}, 134^{\circ} 27^{\prime} 32.6^{\prime \prime} \mathrm{E}$; Site 2: $07^{\circ} 16^{\prime} 27.9^{\prime \prime} \mathrm{N}, 134^{\circ} 27^{\prime} 31.0^{\prime \prime} \mathrm{E}_{\text {; }}$ Site 3: $07^{\circ} 16^{\prime}$ $26.3^{\prime \prime} \mathrm{N}, 134^{\circ} 27^{\prime} 29.0^{\prime \prime} \mathrm{E}$ ). At each site, 3 full cages, 3 partial cages and 3 open plots without cages (all $50 \mathrm{~cm}$ long, $50 \mathrm{~cm}$ wide, $20 \mathrm{~cm}$ high) were set up at a depth of 4 to $6 \mathrm{~m}$, yielding a total of 27 plots. Plots were fixed to the benthos between 20 and 25 February 2017 and were left for $9 \mathrm{wk}$. Pictures were taken weekly throughout the 9 wk on 6 or 8 March, 12 March, 19 March, 27 March, 4 April, 10 April and 27 April 2017. Fifty cells of $1 \mathrm{~cm}$ diameter were placed randomly on each plot and their Lobophora occupancy tracked throughout the study period to analyse Lobophora mortality. 
GoPro cameras (GoPro Hero 3+) were deployed on the 9 open (uncaged) plots used in the $9 \mathrm{wk}$ observational experiment described above, and feeding behaviour was recorded for $4 \mathrm{~h}$ each. Cameras were replaced after about $2 \mathrm{~h}$ due to battery and storage limitations. The cameras were deployed on 3 consecutive days (10 to 12 March 2017). All cameras were deployed around noon and recorded throughout the afternoon to coincide with the highest grazing rates of herbivorous fishes.

\subsubsection{Lobophora recruitment and influence of fish herbivory}

To investigate recruitment in the presence and absence of fish herbivory, 2 sets of caged and uncaged tiles were deployed. The first set comprised 10 caged and 3 uncaged flat cement tiles that were deployed at each of the 3 sites in Lighthouse Reef between 27 September and 3 October 2017. The second set comprised 27 caged and 27 uncaged 'microhabitat' cement tiles that were installed on the reef on 23 March 2018. Both sets of tiles were removed after 3 wk when macroalgal recruits became visible and the number of recruits was counted under a microscope (12x magnification). While there were differences between sets in tile morphology (the microhabitat tiles consisted of easily accessible crowns and concealed crevices; see Doropoulos et al. 2016 for details), in both cases Lobophora recruits were only counted on surfaces easily accessible to herbivores, i.e. the whole surface on the flat tiles and the crowns on the microhabitat tiles. The recruits in the concealed crevices of the microhabitat tiles were not included, as herbivorous fish may have limited access to these areas and could therefore not be compared to easily accessible areas. The number of recruits counted on each tile was standardized by unit area to permit comparison among sets of tiles.

\subsubsection{Species-specific removal of Lobophora recruits}

Although we documented the feeding behaviour of reef fishes on Lobophora as part of the experimental study (described above), such observations do not indicate which species (if any) were responsible for algal mortality. We therefore ran 2 additional experiments to examine the species-specific removal of Lobophora recruits: a controlled tank experiment and an in situ experiment to verify that the findings from the controlled experiment are applicable on a reef.
Tank experiment. A tank experiment was conducted to evaluate the ability of different fish species to remove Lobophora recruits. Forty flat cement tiles $\left(100 \mathrm{~cm}^{2}\right)$ were deployed on 22 September 2018 in cages at 4 to $6 \mathrm{~m}$ depth on Lighthouse Reef and retrieved once Lobophora recruits became visible on 13 October 2018, after $\sim 3 \mathrm{wk}$. Tiles were transported back to the research station and kept in a tank with flow-through seawater until they were used in the experiment (15-27 October 2018). Tiles were mapped under a microscope at $12 \times$ magnification. A grid of $2.5 \times 2.5 \mathrm{~cm}$ was used to map the location of Lobophora recruits on each tile. All recruits were flush against the tile, thereby not reaching a height of more than 2-3 $\mathrm{mm}$ above the substrate. The blade size of the recruits was estimated to be up to $5 \mathrm{~mm}$.

Ten individuals of Acanthurus nigrofuscus, 12 individuals of Ctenochaetus striatus, 10 initial phase (IP) Chlorurus spilurus and 10 Zebrasoma scopas were caught on the inshore reefs of Palau. These fish species are common on Palau's coral reefs and were chosen for the following reasons: A. nigrofuscus is a common grazing surgeonfish with intermediate SCFA levels (Clements \& Choat 1995), meaning it may be able to achieve some nutrition from macroalgae. C. striatus is not expected to have a strong impact on macroalgal recruits due to its feeding ecology and low SCFA levels (Clements \& Choat 1995), but is the most common fish feeding from the benthos in Palau. C. spilurus can be expected to remove Lobophora because of its scraping feeding habit, even though it is unlikely to achieve nutrition directly from macroalgae. Z. scopas may also be able to achieve some nutrition from macroalgal recruits, as it has high SCFA levels and its SCFA profiles are more similar to browsing fishes than most other grazing surgeonfishes (Clements \& Choat 1995, Clements et al. 2017). The fish were transported to the station, where 2 individuals of the same species were moved into a tank $(235 \mathrm{~cm}$ length $\times 95 \mathrm{~cm}$ width $\times 70 \mathrm{~cm}$ depth) and left to acclimatise for $2 \mathrm{~d}$ before the experiments were run. One of the Z. scopas pairs displayed highly aggressive behaviour towards one another, so they had to be separated and only 9 Z. scopas individuals participated in the experiment. Each fish was measured before being released into the tank. The average size of $A$. nigrofuscus was $10.2 \mathrm{~cm}, C$. striatus was $13.6 \mathrm{~cm}, C$. spilurus IP was $13.9 \mathrm{~cm}$, and $Z$. scopas was $10.3 \mathrm{~cm}$. While $A$. nigrofuscus can grow up to a maximum of $21 \mathrm{~cm}$ (fishbase.org), few large individuals were observed, and the average size of $A$. nigrofuscus on Palauan reefs is closer to those used in the study. 
The fish were not starved and had access to turf algae and detritus associated with rubble at all times except during the experimental trials. A tile with turf algae was left in the tank so fish could get used to the presence of a tile in their tank, as we previously observed avoidance behaviour of the fish towards new tiles. The fish often started feeding from tiles after they were in the tank for $2-3 \mathrm{~h}$ and were seen taking regular bites from the tiles that were left in the tank. During the experiment, the tile was replaced with 1 experimental tile in each tank on which feeding behaviour was recorded (GoPro Hero 3+) for $2.5 \mathrm{~h}$. Macroalgal recruits (including Lobophora) and turf algae were present on the experimental tiles. During the trial, all other food sources (e.g. rubble) were removed in order to obtain a sufficient number of bites on the experimental tile. At the beginning of each setup, the grid used for mapping the tiles was held into the frame on top of the tile to allow mapping of bites later (i.e. the grid was removed before the experiment). After the experiment, tiles were remapped as described earlier by counting Lobophora recruits. For each fish species, 5 replicates (with 2 individuals each) were run except for $C$. striatus, for which we ran 6 replicates. A total of 5 controls were run using the same procedure except that fish were unable to feed on the tiles because a cage was added.

In situ experiment. A similar experiment was conducted in situ on the reef using the microhabitat tiles deployed in March 2018 (see description in Section 2.2.2). For the following analyses, only the flat crowns were used because they were readily accessible to all species. To relate fish feeding behaviour to recruit removal, the Lobophora recruits on 15 of these tiles, which had previously been caged, were mapped. Nine of these tiles were deployed on the reef at Site 3 on 8 April 2018 in sets of 3. GoPro Hero $3+$ cameras were set up to observe feeding behaviour of herbivorous fish on the tiles for $4 \mathrm{~h}$ in the absence of divers. Cameras were replaced after about $2 \mathrm{~h}$ due to battery and storage limitations. The other 6 tiles were caged to act as controls. Tiles were retrieved after $4 \mathrm{~h}$ and remapped. All observed bites taken on the flat crowns were counted, the species taking the bite was identified, and the fish length was recorded. Data were only included in the following analysis if only a single species fed at a location.

\subsubsection{Sea urchin density survey}

A survey of sea urchin abundance was conducted on 6 November 2019 at the study site. A total of 80 quadrats $(50 \times 50 \mathrm{~cm})$ were placed randomly on hard reef substrate, and the density and size of sea urchins were recorded. Surveys were conducted during the day, so all crevices and overhanging spaces were extensively searched, as sea urchins often display nocturnality. All individuals were identified to genus level.

\subsection{Statistical analysis}

All statistical analysis was conducted using the program R (version 3.5.0, www.r-project.org), and all generalized linear mixed-effects (GLME) models were computed using the 'Ime4' (Bates et al. 2015) package or the 'glmmTMB' package (Brooks et al. 2017).

\subsubsection{Adult Lobophora dynamics and impact of fish} herbivory on adult Lobophora

Second-order polynomial GLME models with binomial error distribution were fitted to the 50 random cells after visual examination of the cover over time. The response variable was presence/absence of Lobophora within a cell, Treatment and Days were set as interacting fixed factors, and Cell was nested within Plot, which was in turn nested within Site as random factors.

A GLME model with beta distribution was fitted to test for differences in Lobophora cover between the first and the last observation of permanent plots. Treatment and Timepoint were included as interacting fixed factors, and Plot was included as a random factor. A pairwise Tukey post hoc comparison was run using the R package 'emmeans'.

To analyse differences in adult Lobophora survival in response to whether they were caged or exposed to fish herbivory, a Kaplan-Meier curve was created and a survival coxme model was fitted. Coxme survival models allow observations to be censored if the observation period ends before an individual died, i.e. the fate of the individual is unknown after the observational period. Treatment was set as the predictor variable and Plot was nested within Site as a random effect.

Whether fish avoid or target Lobophora was investigated visually by plotting the \% of bites on Lobophora over the \% Lobophora cover. Chi-squared was calculated after averaging \% Lobophora cover, sum of bites observed on Lobophora and expected bites on Lobophora for each of the following fish 
groups: Acanthurus spp., Chlorurus spp., Ctenochaetus spp., Naso spp., Scarus spp. and Zebrasoma spp. To confirm that the bites were correctly identified as being taken on Lobophora or on another substrate type in areas further away from the camera, bites taken in the closer half of the plot to the camera were compared to bites taken in the half further away using separate linear models for parrotfishes and surgeonfishes. Percent bites taken on Lobophora was set as the response variable, whereas Lobophora cover and Plot position (front vs. back) were set as interacting predictor variables.

\subsubsection{Lobophora recruitment and influence of fish herbivory}

The number of Lobophora recruits observed on tiles in September/October 2017 was compared to the recruits counted on the crowns of tiles in March/April 2018. We fitted a negative binomial generalized linear model, with Time and Treatment as fixed factors and included an offset of the tile area to account for the different areas included. Post hoc multiple comparisons were conducted using the 'multcomp' package in R (Hothorn et al. 2008).

\subsubsection{Species-specific removal of Lobophora recruits}

Tank experiment. For the following analyses, only locations where feeding activity occurred were included. Further, Z. scopas consumed some Lobophora recruits only partially. Since partially removed recruits may be able to recover, they were regarded as having 'survived'.

To determine if a fish species was able to remove significantly more recruits than were lost on a control tile, we used a binomial model (see Eqs. S1 \& S2 in the Supplement at www.int-res.com/articles/suppl/ m637p001_supp.pdf) following Harborne et al. (2009), since quasi-complete separation prohibited the use of a GLME model.

A GLME model with binomial distribution was fitted to compare the species' abilities to remove Lobophora recruits. The number of successes and the number of failures of Lobophora removal were bound and set as the response variable, Species was set as a fixed factor and Tile nested within Set-up were set as random factors. Post hoc multiple comparisons were conducted using the 'multcomp' package in R (Hothorn et al. 2008).
In situ experiment. To investigate which species can remove Lobophora recruits in situ, we used the video observations and recruit removal data obtained on the reef. Only locations that originally had Lobophora recruits were included in the analysis. Additionally, locations were only included if a bite was made by a single fish species to avoid confounding results due to multiple species taking bites. This limited the bite data per location and we thus fitted a GLME model with binomial error distribution, setting the probability of a Lobophora mortality event (1 vs. 0) as the response variable. Species (including control) was set as the predictor variable, with a species being recorded if any bites were taken at that location.

\section{RESULTS}

\subsection{Adult Lobophora dynamics and impact of fish herbivory on adult Lobophora}

When herbivorous fishes were excluded in caged plots, Lobophora cover increased throughout the experiment with a slight levelling off after $\sim 40 \mathrm{~d}$. Both the first- and second-order polynomial terms were significant ( $p<0.001$ for both; Fig. 1A). In contrast, when herbivores had access in partially caged and open plots, Lobophora cover increased in March but started to decrease again in April (Fig. 1A). Correspondingly, there was evidence for a second-order polynomial relationship (not different from secondorder polynomial relationship in caged plots; $\mathrm{p}>$ 0.05), but no evidence for a first-order polynomial relationship (significantly different from the linear increase in caged plots; $\mathrm{p}<0.001$ ). Interestingly, there was no change in cover in partial cages and open plots from the first to last time point 9 wk later (open: $p=0.15$, partial: $p=0.53$ ), but there was a significant increase in cover in fully caged plots $(\mathrm{p}<$ 0.05; Fig. 1B).

Lobophora survival did not differ among treatments ( $p>0.05$, Fig. 2 ). The mean \pm SD age was $2.5 \pm$ $3.0 \mathrm{wk}$ in caged treatments, $2.6 \pm 3.8 \mathrm{wk}$ in partially caged treatments and $2.9 \pm 3.3 \mathrm{wk}$ in open treatments.

The percentage of bites taken on Lobophora by both surgeonfishes and parrotfishes increased positively with the cover of Lobophora (Fig. 3). The number of bites taken by parrotfishes on Lobophora was proportionate to the alga's cover (chi-squared: 0.4 and 1.1 for Scarus spp. and Chlorurus spp., respectively). All surgeonfishes, including Acanthurus spp., 

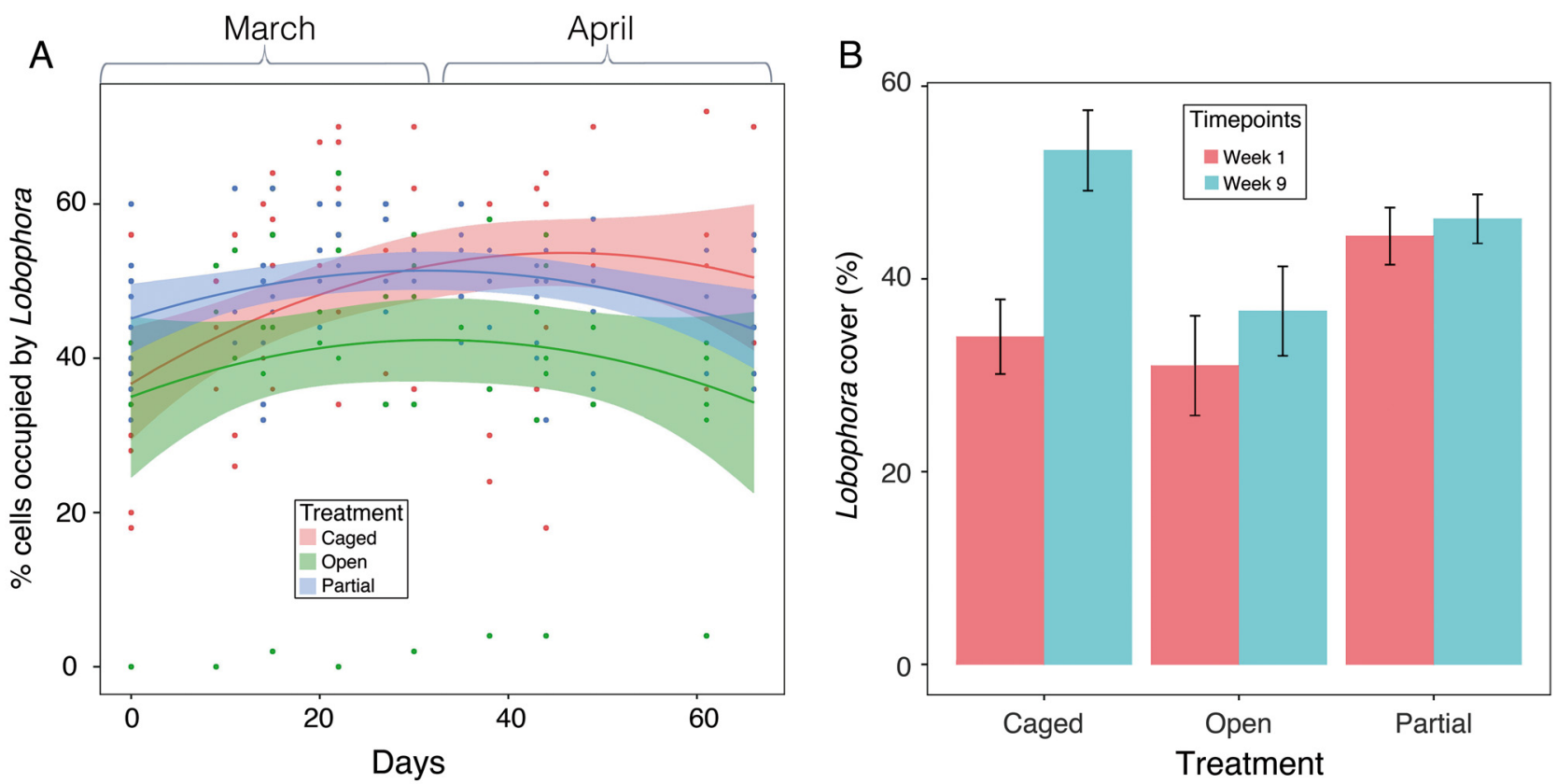

Fig. 1. (A) Percentage Lobophora cover observed over a 9 wk period. Data were obtained through 50 random cells which were followed throughout the experiment. Individual observations and polynomial regressions are displayed. Error margins show $95 \%$ confidence intervals. Treatments are described in Section 2. (B) Percentage of Lobophora cover (mean \pm SE) at the first and last time-point measured

Ctenochaetus spp., Zebrasoma spp. and Naso spp., took more bites on Lobophora than expected (chisquared: 37.7, 83.2, 47.1 and 7.2, respectively; Fig. 3). Identification of the substrate bitten was consistent between the front and the back half of the plot for

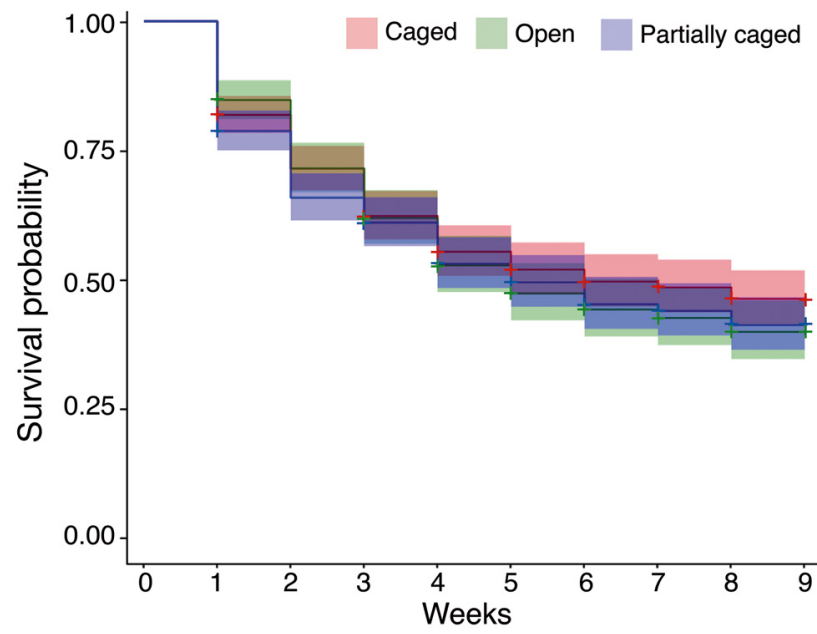

Fig. 2. Kaplan-Meier survival curve using 50 random cells within each plot type (described in Section 2) of which cells occupied by Lobophora were followed throughout a $9 \mathrm{wk}$ period. + symbols show that some cells did not 'die' at that timepoint, but disappeared from observations, which happens when a cell was still alive at the end of the experimental period and its fate is therefore unknown both surgeonfishes and parrotfishes ( $p>0.05$ both), implying that bites taken further away from the camera were recorded correctly.

\subsection{Lobophora recruitment and fish species-specific recruit mortality}

\subsubsection{Recruitment dynamics}

When herbivorous fishes were excluded from tiles in caged treatments, more Lobophora recruits established compared to tiles which allowed access by fish to the algal recruits $(\mathrm{p}<0.001$; Fig. 4$)$. This held true in March/April 2018 and in September/October 2017 ( $\mathrm{p}<0.001$ for both).

More Lobophora recruits were observed in March/ April 2018 compared to September/October 2017. This was the case for caged treatments $(p<0.05$; Fig. 4$)$ and for uncaged treatments $(\mathrm{p}<0.05)$.

\subsubsection{Species-specific removal of Lobophora recruits}

In the tank experiment, only 2 fish species showed a clear impact on recruit mortality. A. nigrofuscus $(\mathrm{p}<0.05)$ and $C$. spilurus $(\mathrm{p}<0.01)$ removed more Lobophora recruits than were lost in control treat- 


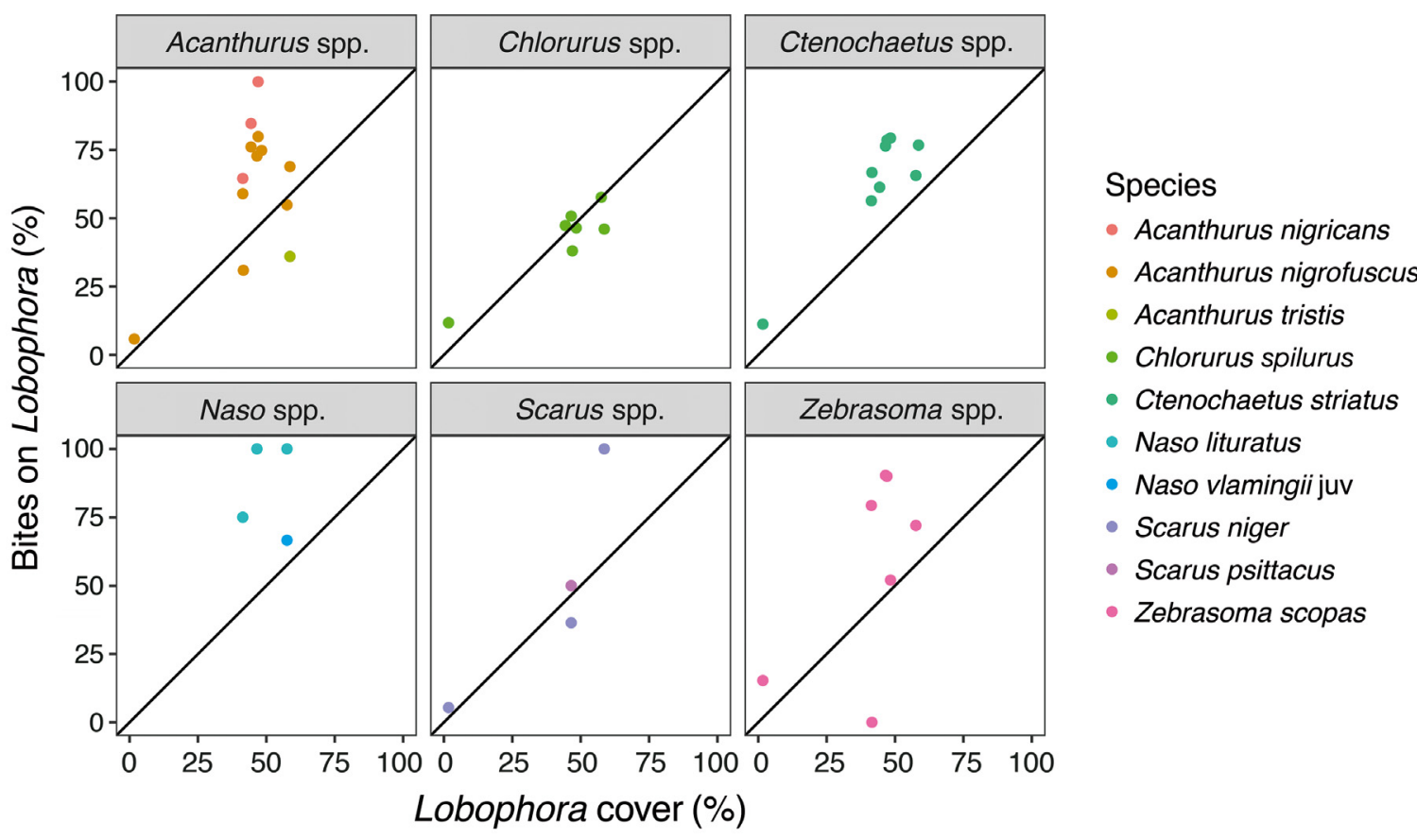

Fig. 3. Percentage of bites taken by surgeonfish and parrotfish on Lobophora in a monitored plot of $50 \times 50 \mathrm{~cm}$ graphed over the percentage Lobophora cover within that plot (as percentage of available area). Dots are individual observations, colours show species identity, and line shows a ratio of 1:1. Dots above the line indicate that more than proportionate amounts of bites were taken, dots below the line indicate fewer bites than expected

ments, whereas C. striatus (p > 0.05) and Z. scopas ( $p>0.05$ ) did not. A. nigrofuscus and C. spilurus did not differ in their ability to remove Lobophora

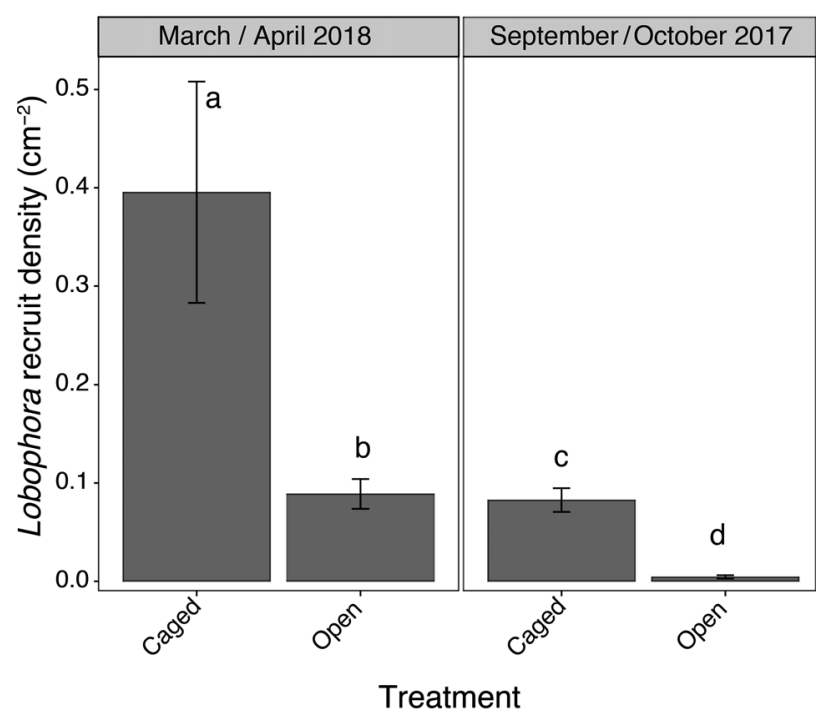

Fig. 4. Comparison of Lobophora recruits on easily accessible crowns of tiles in March 2018 and flat tiles deployed in September 2017. Letters symbolize significantly different results. Mean \pm SE are displayed recruits $(p>0.05)$. C. striatus was also not significantly different from $A$. nigrofuscus or $C$. spilurus, but this observation was based on a single recruit removal. Only A. nigrofuscus and Z. scopas differed significantly, with $A$. nigrofuscus removing more Lobophora recruits than $Z$. Scopas $(p<0.05$; Fig. 5A).

During the in situ experiment where observations of feeding could be linked to a single species at a time, 7 nominally herbivorous fish species visited the tiles. Only A. nigrofuscus and S. niger caused significantly higher Lobophora recruit mortality compared to controls $(p<0.01$ and $p<0.05$, respectively; Fig. 5B). Z. scopas was marginally insignificant ( $\mathrm{p}=$ 0.06), and neither $C$. spilurus, nor Ctenochaetus binotatus, C. striatus or N. lituratus caused Lobophora recruit mortality (all $p>0.05$ ). The maximum number of bites per location, and therefore the likelihood that a recruit may have been removed during non-targeted feeding, varied among species. A. nigrofuscus took a maximum of 2 bites per location, C. spilurus and $S$. niger took a maximum of 3 bites, $C$. binotatus took a maximum of 4 bites, and Z. scopas and N. lituratus each took a maximum of 5 bites. $C$. striatus took the most bites with a maximum of 12 bites per location (Fig. 5B). 

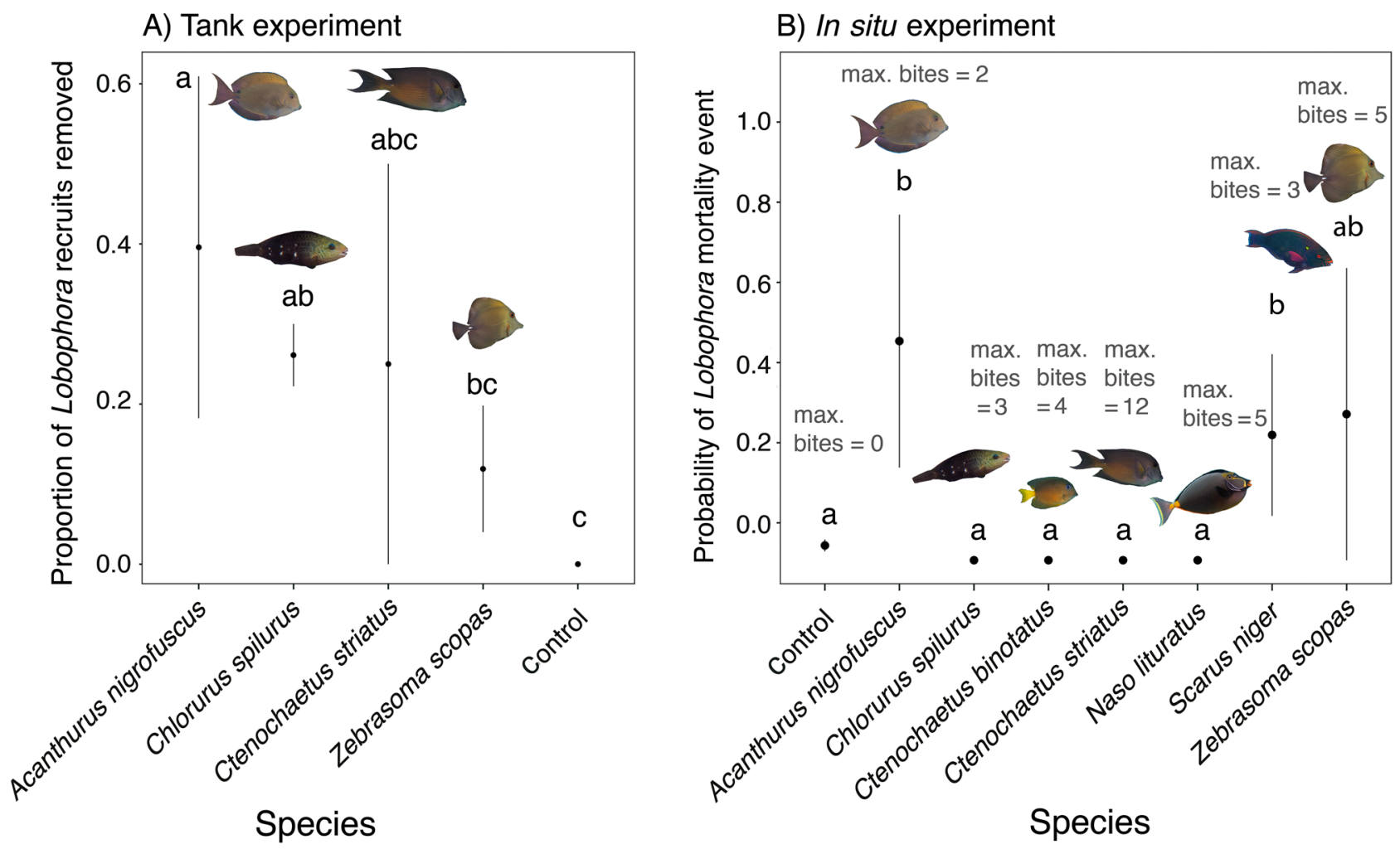

Fig. 5. (A) Mean proportion of Lobophora recruits removed by different fish species during the controlled tank experiment. Letters symbolize significantly different results. Error bars show standard error. (B) Probability of Lobophora recruits being removed when a fish species visited a tile during in situ feeding observations and took bites on locations with Lobophora recruits present. Locations were included when only 1 species took bites on them to avoid confounding feeding by multiple species on the same recruit location. Letters symbolize significantly different results. max. bites: maximum number of bites taken at 1 location

\subsection{Sea urchin density}

The density of sea urchins at Lighthouse Reef was low, with a mean $\pm \mathrm{SE}$ of $0.3 \pm 0.1$ ind. $\mathrm{m}^{-2}$. All sea urchins found belonged to the genera Echinostrephus and Echinometra in the family Echinometridae. The size (diameter) of the echinometrids ranged from 10 to $22 \mathrm{~mm}$. The mean \pm SD size of Echinostrephus was $11.3 \pm 1.2 \mathrm{~mm}$, while Echinometra was $20.7 \pm$ $2.3 \mathrm{~mm}$. No diadematids were found at our study site.

\section{DISCUSSION}

While grazing activity severely reduced recruit establishment, control of adult algae was limited. However, the ability of fish species to remove recruits varied considerably. Out of 7 species observed, only Acanthurus nigrofuscus, Chlorurus spilurus and Scarus niger removed Lobophora recruits. These species-specific algal-fish interactions highlight the need to consider species-level behaviours driving or preventing shifts to macroalgal dominance.

Fish herbivory had a stronger influence on Lobophora recruit establishment and mortality compared to adult Lobophora mortality. During the $2.5 \mathrm{~h}$ tank experiment, up to $40 \%$ of recruits were removed depending on the fish species involved. During the $4 \mathrm{~h}$ in situ observations, fish caused a mortality event with up to $50 \%$ probability. Additionally, over $3 \mathrm{wk}$, 78 to $95 \%$ fewer recruits became established when they were exposed to herbivores. These values are similar to the herbivore-driven spore and growth reductions of other algal species (Lotze et al. 1999).

In contrast, we found much less impact of herbivory on adult Lobophora. The trajectory of Lobophora cover differed between caged vs. open plots and partially caged treatments, which implies that herbivores did influence Lobophora trajectories in some way. While caged plots showed a linear increase in cover, the cover in open and partial cages increased for about 4 wk before decreasing again to a similar Lobophora cover as recorded at the beginning of the 
experiment. Indeed, when herbivores had access to the adult algal patches, overall Lobophora cover did not change from the first timepoint to 9 wk later (Fig. 1B). However, cover did increase by $19.3 \%$ in cages. This indicates that there is an equilibrium between herbivory and Lobophora growth when herbivores have access to the alga, but when herbivory is reduced, the alga can increase its cover. Interestingly, adult Lobophora survival was independent of herbivore access, indicating that the observed change in cover may be driven by the establishment of new algae rather than the consumption of established Lobophora thalli. Given the low number of fish species that can be expected to derive nutrition from adult Lobophora (Horn 1989, Choat et al. 2002), this pattern is not surprising. These findings indicate that adult Lobophora may be less susceptible to grazing by herbivorous fishes than recruits, but further research is necessary to explore this hypothesis specifically by investigating the removal of an equivalent amount of adult and recruit biomass.

While we did not test whether the lower removal of adult algae was driven by chemical (e.g. secondary metabolites) or morphological (e.g. size) changes in the alga, there is some support for both concepts. Apart from differences in their sizes, recruits are relatively flush against the substrate (which also sets them apart from other macroalgal recruits), but are only attached by 1 holdfast, whereas adult encrusting or decumbent Lobophora of the same species are well attached to large areas of the substrate (L.D. Puk pers. obs.). Along with larger sizes, these morphological differences would make the removal of adult Lobophora much more difficult than the removal of recruits. Phlorotannins, secondary metabolites of brown macroalgae, polymerize and increase in size as they age (Targett \& Arnold 2001), which makes them more likely to interfere with the digestion of other macromolecules (Boettcher \& Targett 1993). However, the aging process is quite rapid and has been observed over a few hours (Targett \& Arnold 2001). It is therefore unclear whether this mechanism would act over weeks or months as would be required to explain differences between adult and recruit chemical defences. Whichever mechanism dominates, our findings suggest decreased herbivory on adult algae compared to recent recruits as predicted by the growth-differentiation balance (Herms \& Mattson 1992). This ontogenetic decrease in grazing may be more pronounced in Lobophora than in other macroalgae, because recruit removal rates were similar to other algae (Lotze et al. 1999), whereas Lobophora adult removal was low compared to the consumption of other macroalgal species (Hoey \& Bellwood 2010, Bennett \& Bellwood 2011).

The ability of herbivorous fishes to control Lobophora recruits is species-specific. The grazing surgeonfish A. nigrofuscus removed Lobophora recruits in both the controlled tank experiment and the feeding observations on the reef, whereas the grazing/detritivorous surgeonfish Ctenochaetus striatus did not remove recruits in either of the 2 experiments. While C. striatus was not significantly different from A. nigrofuscus and C. spilurus in tank experiments (likely an artefact of the high variance observed for C. striatus), the ability of this species to control Lobophora seems very limited. The lack of recruit removal in situ, where C. striatus took by far the highest number of bites without causing Lobophora mortality, corroborates its likely minimal impact on Lobophora. This is an important difference between $A$. nigrofuscus and $C$. striatus, as $C$. striatus is one of the most abundant herbivorous fishes on Indo-Pacific reefs (Russ 1984, Cheal et al. 2012), but our study indicates that it is unable to control outbreaks of macroalgae like Lobophora.

The grazing tang Zebrasoma scopas did not remove Lobophora recruits in either the tank experiment or the in situ experiment. However, we found multiple Lobophora that had been partially removed by Z. scopas. It therefore seems that Z. scopas does feed on Lobophora recruits, but whether its feeding activity has any impact on the survival of Lobophora recruits is unknown and would require longer-term monitoring of recruit growth and survival when exposed to Z. scopas.

The fourth species observed both in situ and in the tank was the parrotfish C. spilurus, which removed recruits in the tank experiment but did not remove any recruits in situ. It is possible that C. spilurus avoided Lobophora recruits in situ, because parrotfish have been identified as microphages, which target microorganisms such as cyanobacteria (Clements et al. 2017). However, while foraging for microorganisms in the reef substrate, C. spilurus ingests algae because of its excavating feeding mode (Bellwood \& Choat 1990). Further, the morphological adaptations of C. spilurus for excavating reef substrate while feeding means they remove more substrate than the scraping parrotfish S. niger (Bellwood \& Choat 1990), which removed recruits in situ. It is therefore likely that C. spilurus does remove Lobophora recruits during its foraging, and the lack of evidence from the field is due to the low number of bites observed. While Naso lituratus, a common browser adapted to 
removing macroalgae (Choat et al. 2004, Rasher et al. 2013, Plass-Johnson et al. 2015), did not remove any recruits in our in situ study, we have only limited data on $N$. lituratus (2 forages) and cannot draw conclusions about its ability to remove Lobophora recruits on a reef scale. Overall, our experiments show important differences in the ability of fish species to remove Lobophora recruits.

While Lobophora recruits are readily removed by multiple species, adult Lobophora are often persistent though time (Van den Hoek et al. 1978, de Ruyter van Steveninck \& Breeman 1987a, Roff et al. 2015), and only a few herbivore species are expected to control the alga (Horn 1989, Choat \& Clements 1998). Two groups of herbivorous fishes reported to remove adult Lobophora are rabbitfishes (Pillans et al. 2004, Bennett et al. 2010, Vieira et al. 2019), which were rare at our study site, and parrotfishes (Roff et al. 2015). Parrotfish took a proportionate number of bites on Lobophora during our study, indicating that they neither target it nor do they avoid the alga, which is in line with their feeding ecology (Clements et al. 2017). Because of the lack of Lobophora avoidance and the ability of parrotfish to scrape the reef substratum clean of algae, parrotfish have incidental impacts on Lobophora. In contrast to parrotfish, unicornfish Naso spp., which are able to digest macroalgae (Choat et al. 2004), consistently took disproportionately many bites on the alga. Other surgeonfish species are highly unlikely to remove adult Lobophora, especially the encrusting morphology dominating in Palau (L. D. Puk pers. obs.), because of their jaw morphology (Purcell \& Bellwood 1993) and gut physiology, which is unsuitable for macroalgal digestion (Horn 1989, Choat et al. 2004). It is more probable that surgeonfish target either the turf algae, epiphytes or detritus growing on the surface of Lobophora (Fricke et al. 2011, Eich et al. 2019) and therefore have little direct influence on Lobophora. It is interesting to note that no avoidance behaviour of adult Lobophora patches was observed, a behaviour previously shown in other adult macroalgal patches (McClanahan et al. 1999, Hoey \& Bellwood 2011). While the reason for this is unknown, it is possible that the lack of physical structure of the mostly encrusting Lobophora cover could lead to less avoidance behaviour than observed, for example, for Sargassum (Hoey \& Bellwood 2011). Generally, it seems that the removal of adult Lobophora is limited to few fish species, including parrotfish and potentially browsing herbivores.

The density of sea urchins at our study site was low, with a mean \pm SE of $0.3 \pm 0.1$ ind. $\mathrm{m}^{-2}$ and a mean size (diameter) of $16 \pm 2.2 \mathrm{~mm}$. Sea urchins can be major grazing agents on Lobophora, as shown for Diadema in the Caribbean and Canary Islands, but namely at high population densities ( $>2$ ind. $\mathrm{m}^{-2}$ ) (de Ruyter van Steveninck \& Breeman 1987a, Tuya et al. 2001, Hernández et al. 2008). Only 2 genera of small (10 to $22 \mathrm{~mm}$ diameter) echinometrids were found at our study site (Echinostrephus and Echinometra), with no observations of larger-bodied Diadema. Predators tend to restrict echinometrids to crevices, which reduces their influence on exposed fleshy algae, including Lobophora (McClanahan 1999). Furthermore, Echinometra show food preferences for turf macroalgae (e.g. Acanthophora) while avoiding Lobophora (Sangil \& Guzman 2016). While feeding behaviour on Lobophora adults and recruits was only recorded during the day (and sea urchin activity tends to be greatest at night), the species composition, low density and small size of sea urchins at our site suggest that their influence on Lobophora cover would be minimal.

Variable Lobophora growth and recruitment was observed at different times of the year. Independent of whether herbivores had access to Lobophora, the alga's cover increased over $4 \mathrm{wk}$, indicating that herbivory did not control its growth sufficiently. After 4 wk, Lobophora in caged treatments without herbivore access kept growing until it plateaued after around $6 \mathrm{wk}$, which could have been driven by a reduction in growth during the second half of the experiment. In contrast, Lobophora in partial and open treatments, which allowed herbivore access, declined again after Week 4 until the end of the experiment. This decline in Lobophora cover shows that herbivory during the second half of the experiment was able to reverse Lobophora growth, possibly because of reduced growth rates. Similar to Lobophora cover, Lobophora recruitment showed variability throughout time, with 4 times higher recruitment rates in March 2018 compared to September 2017. While our data do not allow us to conclude that this variability is driven by seasonality, Lobophora has previously been found to be highly seasonal in the Indo-Pacific (Diaz-Pulido et al. 2009), and maximum Lobophora cover was observed in April in Palau (Roff et al. 2015). Repeated multi-year observations would be necessary to assess seasonality of Lobophora. Temporally variable growth has implications at the scale of entire reefs. If reductions in grazing pressure, for example through fishing or increases in grazable area after mass coral mortality, co-occur with peak growth and recruitment, it may have a much more substantial ecological impact than 
grazing reductions during low growth and recruitment times. The timing of disturbances may therefore play a role in the formation of Lobophora blooms, which can subsequently persist for several years (Roff et al. 2015, Bozec et al. 2019).

Overall, we found that herbivorous fishes readily removed Lobophora recruits, but this removal was driven by only a few species. In contrast, removal of adult Lobophora was comparably low. In a world of increasing macroalgal proliferation on coral reefs, fish species able to remove macroalgal recruits and thereby prohibit the establishment of more resistant adult populations, such as A. nigrofuscus and parrotfishes, are important for the resilience of coral reefs. The abundance of these key species should thus be monitored, and fishing regulations should be considered by managers.

Acknowledgements. We thank Shannen Smith, Kelly Wong and Alex Tredinnick for their help during field work. We are also grateful to the Palau International Coral Reef Center for providing us with the space necessary to conduct our studies. This research was funded by the Winnifred Violet Scott Trust and by ARC grants awarded to P.J.M.

\section{LITERATURE CITED}

Appel HM (1993) Phenolics in ecological interactions: the importance of oxidation. J Chem Ecol 19:1521-1552

Arnold TM, Tanner CE, Hatch WI (1995) Phenotypic variation in polyphenolic content of the tropical brown alga Lobophora variegata as a function of nitrogen availability. Mar Ecol Prog Ser 123:177-183

Barton KE, Koricheva J (2010) The ontogeny of plant defense and herbivory: characterizing general patterns using meta-analysis. Am Nat 175:481-493

Bates D, Mächler M, Bolker B, Walker S (2015) Fitting linear mixed-effects models using lme4. J Stat Softw 67:1-48

Bellwood DR, Choat JH (1990) A functional analysis of grazing in parrotfishes (family Scaridae): the ecological implications. Environ Biol Fishes 28:189-214

Bellwood DR, Hughes TP, Hoey AS (2006) Sleeping functional group drives coral-reef recovery. Curr Biol 16: 2434-2439

*Bennett S, Bellwood DR (2011) Latitudinal variation in macroalgal consumption by fishes on the Great Barrier Reef. Mar Ecol Prog Ser 426:241-252

Bennett S, Vergés A, Bellwood DR (2010) Branching coral as a macroalgal refuge in a marginal coral reef system. Coral Reefs 29:471-480

Boettcher AA, Targett NM (1993) Role of polyphenolic molecular size in reduction of assimilation efficiency in Xiphister mucosus. Ecology 74:891-903

Box SJ, Mumby PJ (2007) Effect of macroalgal competition on growth and survival of juvenile Caribbean corals. Mar Ecol Prog Ser 342:139-149

Bozec YM, Doropoulos C, Roff G, Mumby PJ (2019) Transient grazing and the dynamics of an unanticipated coral-algal phase shift. Ecosystems 22:296-311

Brooks ME, Kristensen K, van Benthem KJ, Magnusson A and others (2017) glmmTMB balances speed and flexibility among packages for zero-inflated generalized linear mixed modeling. R J 9:378-400

Bryant JP, Reichardt PB, Clausen TP, Provenza FD, Kuropat P (1992) Woody plant-mammal interactions. In: Rosenthal GA, Berenbaum MR (eds) Herbivores: their interactions with plant secondary metabolites. Academic Press, San Diego, CA, p 344-371

* Carpenter RC (1986) Partitioning herbivory and its effects on coral reef algal communities. Ecol Monogr 56: 345-363

Cheal A, Emslie M, Miller I, Sweatman H (2012) The distribution of herbivorous fishes on the Great Barrier Reef. Mar Biol 159:1143-1154

Choat JH, Clements KD (1998) Vertebrate herbivore in marine and terrestrial environments: a nutritional ecology perspective. Annu Rev Ecol Syst 29:375-403

Choat JH, Clements KD, Robbins WD (2002) The trophic status of herbivorous fishes on coral reefs. I. Dietary analyses. Mar Biol 140:613-623

Choat JH, Robbins WD, Clements KD (2004) The trophic status of herbivorous fishes on coral reefs. II. Food processing modes and trophodynamics. Mar Biol 145:445-454

Cipollini DF Jr, Redman AM (1999) Age-dependent effects of jasmonic acid treatment and wind exposure on foliar oxidase activity and insect resistance in tomato. $\mathrm{J}$ Chem Ecol 25:271-281

Clements KD, Choat JH (1995) Fermentation in tropical marine herbivorous fishes. Physiol Zool 68:355-378

Clements KD, Choat JH (1997) Comparison of herbivory in the closely-related marine fish genera Girella and Kyphosus. Mar Biol 127:579-586

Clements KD, Gleeson VP, Slaytor M (1994) Short-chain fatty acid metabolism in temperate herbivorous fish. J Comp Physiol B Biochem Syst Environ Physiol 164: 372-377

Clements KD, German DP, Piché J, Tribollet A, Choat JP (2017) Integrating ecological roles and trophic diversification on coral reefs: multiple lines of evidence identify parrotfishes as microphages. Biol J Linn Soc 120:729-751

Coen LD, Tanner CE (1989) Morphological variation and differential susceptibility to herbivory in the tropical brown alga Lobophora variegata. Mar Ecol Prog Ser 54: 287-298

Connell JH, Hughes TP, Wallace CC (1997) A 30-year study of coral abundance, recruitment, and disturbance at several scales in space and time. Ecol Monogr 67:461-488

*Dahlgren CP, Eggleston DB (2000) Ecological processes underlying ontogenetic habitat shifts in a coral reef fish. Ecology 81:2227-2240

* de Ruyter van Steveninck ED, Breeman AM (1987a) Deep water vegetations of Lobophora variegata (Phaeophyceae) in the coral reef of Curaçao: population dynamics in relation to mass mortality of the sea urchin Diadema antillarum. Mar Ecol Prog Ser 36:81-90

* de Ruyter van Steveninck ED, Breeman AM (1987b) Deep water populations of Lobophora variegata (Phaeophyceae) on the coral reef of Curaçao: influence of grazing and dispersal on distribution patterns. Mar Ecol Prog Ser 38:241-250

Diaz-Pulido G, McCook LJ (2003) Relative roles of herbivory and nutrients in the recruitment of coral-reef seaweeds. Ecology 84:2026-2033

*Diaz-Pulido G, McCook LJ, Dove S, Berkelmans R and others 
(2009) Doom and boom on a resilient reef: climate change, algal overgrowth and coral recovery. PLOS ONE 4:e5239

Doropoulos C, Roff G, Bozec YM, Zupan M, Werminghausen J, Mumby PJ (2016) Characterizing the ecological trade-offs throughout the early ontogeny of coral recruitment. Ecol Monogr 86:20-44

Eich A, Ford AK, Nugues MM, McAndrews RS, Wild C, Ferse SCA (2019) Positive association between epiphytes and competitiveness of the brown algal genus Lobophora against corals. PeerJ 7:e6380

Evans RD, Wilson SK, Field SN, Moore JAY (2014) Importance of macroalgal fields as coral reef fish nursery habitat in north-west Australia. Mar Biol 161:599-607

Evensen NR, Doropoulos C, Wong KJ, Mumby PJ (2019) Stage-specific effects of Lobophora on the recruitment success of a reef-building coral. Coral Reefs 38:489-498

Feeny P (1970) Seasonal changes in oak leaf tannins and nutrients as a cause of spring feeding by winter moth caterpillars. Ecology 51:565-581

Ferrari R, Gonzalez-Rivero M, Mumby PJ (2012) Size matters in competition between corals and macroalgae. Mar Ecol Prog Ser 467:77-88

Foster NL, Box SJ, Mumby PJ (2008) Competitive effects of macroalgae on the fecundity of the reef-building coral Montastraea annularis. Mar Ecol Prog Ser 367: 143-152

*Fox RJ, Bellwood DR (2008) Remote video bioassays reveal the potential feeding impact of the rabbitfish Siganus canaliculatus (f: Siganidae) on an inner-shelf reef of the Great Barrier Reef. Coral Reefs 27:605-615

Fricke A, Titlyanova TV, Nugues MM, Bischof K (2011) Depth-related variation in epiphytic communities growing on the brown alga Lobophora variegata in a Caribbean coral reef. Coral Reefs 30:967-973

Fritz RS, Hochwender CG, Lewkiewicz DA, Bothwell S, Orians CM (2001) Seedling herbivory by slugs in a willow hybrid system: developmental changes in damage, chemical defense, and plant performance. Oecologia 129:87-97

Gilbert LE (1971) Butterfly-plant coevolution: Has Passiflora adenopoda won the selectional race with heliconiine butterflies? Science 172:585-586

Goodger JQD, Gleadow RM, Woodrow IE (2006) Growth cost and ontogenetic expression patterns of defence in cyanogenic Eucalyptus spp. Trees 20:757-765

Green AL, Bellwood DR (eds) (2009) Monitoring functional groups of herbivorous reef fishes as indicators of coral reef resilience: a practical guide for coral reef managers in the Asia Pacific Region. IUCN, Gland

* Gruner DS, Smith JE, Seabloom EW, Sandin SA and others (2008) A cross-system synthesis of consumer and nutrient resource control on producer biomass. Ecol Lett 11: $740-755$

Harborne A, Renaud P, Tyler E, Mumby P (2009) Reduced density of the herbivorous urchin Diadema antillarum inside a Caribbean marine reserve linked to increased predation pressure by fishes. Coral Reefs 28:783-791

Hay ME (1981) Spatial patterns of grazing intensity on a Caribbean barrier reef: herbivory and algal distribution. Aquat Bot 11:97-109

Herms DA, Mattson WJ (1992) The dilemma of plants: to grow or defend. Q Rev Biol 67:283-335

Kernández JC, Clemente S, Sangil C, Brito A (2008) The key role of the sea urchin Diadema aff. antillarum in controlling macroalgae assemblages throughout the Canary
Islands (eastern subtropical Atlantic): an [sic] spatiotemporal approach. Mar Environ Res 66:259-270

*Hoey AS, Bellwood DR (2010) Cross-shelf variation in browsing intensity on the Great Barrier Reef. Coral Reefs 29:499-508

Hoey AS, Bellwood DR (2011) Suppression of herbivory by macroalgal density: a critical feedback on coral reefs? Ecol Lett 14:267-273

Horn MH (1989) Biology of marine herbivorous fishes. Oceanogr Mar Biol Annu Rev 27:167-272

Hothorn T, Bretz F, Westfall P (2008) Simultaneous inference in general parametric models. Biom J 50:346-363

Hughes TP (1994) Catastrophes, phase shifts, and largescale degradation of a Caribbean coral reef. Science 265: 1547-1551

Jompa J, McCook LJ (2002a) The effects of nutrients and herbivory on competition between a hard coral (Porites cylindrica) and a brown alga (Lobophora variegata). Limnol Oceanogr 47:527-534

Jompa J, McCook LJ (2002b) Effects of competition and herbivory on interactions between a hard coral and a brown alga. J Exp Mar Biol Ecol 271:25-39

Kearsley MJC, Whitham TG (1989) Developmental changes in resistance to herbivory: implications for individuals and populations. Ecology 70:422-434

Kuffner IB, Walters LJ, Becerro MA, Paul VJ, RitsonWilliams R, Beach KS (2006) Inhibition of coral recruitment by macroalgae and cyanobacteria. Mar Ecol Prog Ser 323:107-117

* Ledlie MH, Graham NAJ, Bythell JC, Wilson SK, Jennings S, Polunin NVC, Hardcastle J (2007) Phase shifts and the role of herbivory in the resilience of coral reefs. Coral Reefs 26:641-653

* Loney PE, McArthur C, Potts BM, Jordan GJ (2006) How does ontogeny in a Eucalyptus species affect patterns of herbivory by brushtail possums? Funct Ecol 20:982-988

Lotze HK, Schramm W, Schories D, Worm B (1999) Control of macroalgal blooms at early developmental stages: Pilayella littoralis versus Enteromorpha spp. Oecologia 119:46-54

Kubchenco J (1983) Littorina and Fucus: effects of herbivores, substratum heterogeneity, and plant escapes during succession. Ecology 64:1116-1123

*Mantyka CS, Bellwood DR (2007) Direct evaluation of macroalgal removal by herbivorous coral reef fishes. Coral Reefs 26:435-442

Marshell AL (2014) The grazing impact of common surgeonfish on algal dynamics of the Great Barrier Reef. PhD thesis, The University of Queensland, Brisbane

*McClanahan TR (1999) Predation and the control of the sea urchin Echinometra viridis and fleshy algae in the patch reefs of Glovers Reef, Belize. Ecosystems 2:511-523

McClanahan TR, Muthiga NA (1998) An ecological shift in a remote coral atoll of Belize over 25 years. Environ Conserv 25:122-130

*McClanahan TR, Hendrick V, Rodrigues MJ, Polunin NVC (1999) Varying responses of herbivorous and invertebrate-feeding fishes to macroalgal reduction on a coral reef. Coral Reefs 18:195-203

* McConnell OJ, Hughes PA, Targett NM, Daley J (1982) Effects of secondary metabolites from marine algae on feeding by the sea urchin, Lytechinus variegatus. J Chem Ecol 8:1437-1453

* Miller MW, Hay ME, Miller SL, Malone D, Sotka EE, Szmant AM (1999) Effects of nutrients versus herbivores on reef 
algae: a new method for manipulating nutrients on coral reefs. Limnol Oceanogr 44:1847-1861

Moberg F, Folke C (1999) Ecological goods and services of coral reef ecosystems. Ecol Econ 29:215-233

Nyström M, Graham NAJ, Lokrantz J, Norström AV (2008) Capturing the cornerstones of coral reef resilience: linking theory to practice. Coral Reefs 27:795-809

Painter TJ (1983) Algal polysaccharides. In: Aspinall GO (ed) The polysaccharides, Vol 2. Academic Press, New York, NY, p 195-285

Paul VJ, Hay ME (1986) Seaweed susceptibility to herbivory: chemical and morphological correlates. Mar Ecol Prog Ser 33:255-264

Pillans RD, Franklin CE, Tibbetts IR (2004) Food choice in Siganus fuscescens: influence of macrophyte nutrient content and availability. J Fish Biol 64:297-309

" Plass-Johnson JG, Ferse SCA, Jompa J, Wild C, Teichberg $M$ (2015) Fish herbivory as key ecological function in a heavily degraded coral reef system. Limnol Oceanogr 60: 1382-1391

Polunin NV, Klumpp D (1992) Algal food supply and grazer demand in a very productive coral-reef zone. J Exp Mar Biol Ecol 164:1-15

Puk LD, Ferse SCA, Wild C (2016) Patterns and trends in coral reef macroalgae browsing: a review of browsing herbivorous fishes of the Indo-Pacific. Rev Fish Biol Fish 26:53-70

Purcell SW, Bellwood DR (1993) A functional analysis of food procurement in two surgeonfish species, Acanthurus nigrofuscus and Ctenochaetus striatus (Acanthuridae). Environ Biol Fishes 37:139-159

Rasher DB, Hay ME (2010) Chemically rich seaweeds poison corals when not controlled by herbivores. Proc Natl Acad Sci USA 107:9683-9688

Rasher DB, Hoey AS, Hay ME (2013) Consumer diversity interacts with prey defenses to drive ecosystem function. Ecology 94:1347-1358

Roff G, Doropoulos C, Zupan M, Rogers A, Steneck RS, Golbuu Y, Mumby PJ (2015) Phase shift facilitation following cyclone disturbance on coral reefs. Oecologia 178: 1193-1203

Russ GR (1984) Distribution and abundance of herbivorous grazing fishes in the central Great Barrier Reef. II. Patterns of zonation of mid-shelf and outershelf reefs. Mar Ecol Prog Ser 20:35-44

Sangil C, Guzman HM (2016) Assessing the herbivore role of the sea-urchin Echinometra viridis: keys to determine the structure of communities in disturbed coral reefs. Mar Environ Res 120:202-213

Saunders DR, Wiggins HS (1981) Conservation of mannitol, lactulose, and raffinose by the human colon. Am J Physiol 241:G397-G402

Seeto GS, Veivers PC, Clements KD, Slaytor M (1996) Car-

Editorial responsibility: Tim McClanahan,

Mombasa, Kenya bohydrate utilisation by microbial symbionts in the marine herbivorous fishes Odax cyanomelas and Crinodus lophodon. J Comp Physiol B Biochem Syst Environ Physiol 165:571-579

Spiegel LH, Price PW (1996) Plant aging and the distribution of Rhyacionia neomexicana (Lepidoptera: Tortricidae). Environ Entomol 25:359-365

Steneck RS, Bellwood DR, Hay ME (2017) Herbivory in the marine realm. Curr Biol 27:R484-R489

Stern JL, Hagerman AE, Steinberg PD, Mason PK (1996) Phlorotannin-protein interactions. J Chem Ecol 22: 1877-1899

Sun Z, Hanyuda T, Lim PE, Tanaka J, Gurgel CFD, Kawai H (2012) Taxonomic revision of the genus Lobophora (Dictyotales, Phaeophyceae) based on morphological evidence and analyses $r b c \mathrm{~L}$ and cox3 gene sequences. Phycologia 51:500-512

Targett NM, Arnold TM (2001) Effects of secondary metabolites on digestion in marine herbivores. In: McClintock JB, Baker BJ (eds) Marine chemical ecology. CRC Press, Boca Raton, FL, p 391-412

* Targett NM, Boettcher AA, Targett TE, Vrolijk NH (1995) Tropical marine herbivore assimilation of phenolic-rich plants. Oecologia 103:170-179

* Tuya F, Martín JA, Reuss GM, Luque A (2001) Food preferences of the sea urchin Diadema antillarum in Gran Canaria (Canary Islands, central-east Atlantic Ocean). J Mar Biol Assoc UK 81:845-849

Van den Hoek C, Breeman AM, Bak RPM, Van Buurt G (1978) Distribution of algae, corals and gorgonians in relation to depth, light attenuation, water movement and grazing pressure in fringing coral-reef of Curaçao, Netherlands Antilles. Aquat Bot 5:1-46

* Vieira C, D'hondt S, De Clerck O, Payri CE (2014) Toward an inordinate fondness for stars, beetles and Lobophora? Species diversity of the genus Lobophora (Dictyotales, Phaeophyceae) in New Caledonia. J Phycol 50: 1101-1119

Vieira C, Payri C, De Clerck O (2015) Overgrowth and killing of corals by the brown alga Lobophora hederacea (Dictyotales, Phaeophyceae) on healthy reefs in New Caledonia: a new case of the epizoism syndrome. Phycol Res 63:152-153

Vieira C, Stenger PL, Moleana T, De Clerck O, Payri CE (2019) Limited interspecific variation in grazing susceptibility of the brown alga Lobophora to herbivory. J Exp Mar Biol Ecol 518:151175

*Weidner K, Lages BG, da Gama BAP, Molis M, Wahl M, Pereira RC (2004) Effect of mesograzers and nutrient levels on induction of defenses in several Brazilian macroalgae. Mar Ecol Prog Ser 283:113-125

Whittaker RH, Feeny PP (1971) Allelochemics: Chemical interactions between species. Science 171:757-770

Submitted: September 5, 2019; Accepted: February 11, 2020

Proofs received from author(s): February 27, 2020 